\title{
'When the cat is away, the mice will play': the political ecology of tobacco production and manganese mining in Nansanga farm block in Zambia
}

\author{
Andrew Chilombo ${ }^{1}$ \\ Dan van der Horst \\ UNEP West Africa sub-Regional Office, Ivory Coast \\ University of Edinburgh, Scotland, UK
}

\begin{abstract}
Large-scale land acquisitions (LSLAs) have emerged as an important policy issue in development discourse. Governments in host countries play a critical role in engineering policy landscapes for enclosing local community resources for capital accumulation by business entities with greater financial resources and access to power. Case studies have highlighted failed implementation of LSLA deals, resulting in cancellations, scaling down, abandonment or change of investment business models. However, few attempts have been made to understand what accounts for such failures and what happens when both state policy and private sector implementation of land deals fail. Taking Nansanga farm block, a government of Zambia-led LSLA deal currently in limbo, this article presents a study that aimed at understanding the political ecology of tobacco production and manganese mining as opportunistic economic activities - that is, activities that are taking advantage of new infrastructure created by an otherwise 'failed' government project and flourishing in an area where local peoples' rights were previously protected through customary tenure. Drawing on stakeholder interviews, the study shows that the government's role in the development of Nansanga vanished; creating a development vacuum that opened the door to opportunistic tobacco production and open pit manganese mining. Tobacco and mining, heavily extractive as they are of forest resources, have emerged as double-edged swords: in the short-term increasing financial inflows and job creation, and, but also leading to labor flight from production of traditional crops, deforestation and land degradation, and anomie and deracination in some cases as land use and land users are (re)defined.
\end{abstract}

Keywords: Zambia, Nansanga, large-scale land acquisitions, political ecology, tobacco, Manganese

\footnotetext{
${ }^{1}$ Dr. Andrew Chilombo is a consultant for the UNEP West Africa sub-Regional Office, Division of Ecosystems, in Ivory Coast. Email: chilombos "at" yahoo.co.uk. Dr. Dan van der Horst is a Senior Lecturer in Environment, Energy and Society, School of GeoSciences, University of Edinburgh, Scotland. Email: dan.vanderhorst "at"ed.ac.uk. Acknowledgements: This research was part of the first author's 2016 University of Edinburgh Southern African PhD Research Scholarship. Additional financial support came from the School of GeoSciences Centenary Agroforestry 89 Fund, University of Edinburgh. We thank Mr. Kabamba Ezekiah of Mindolo Teachers Training College and the research assistants, Mr. Moses Chiposa, Mr. Edwin Shiaka and Mr. Mweemba Sunya from the Copperbelt University who supported us with data collection. We thank Mr. Herald Mwape, the Senior Chief advisor in Mingomba, and the Village headman in Kabundi for facilitating our engagements with community members. Acknowledgements are extended to Mr. Simon Mulenga and Mr. Rodrick Mwape for providing accommodation during the field visits within Nansanga. We also thank Ms Magdalena Canales Redondo for proof-reading the Spanish version of the abstract. Finally, we thank the editorial and review team for their insightful comments that helped to strengthen this article.
} 


\section{Résumé}

Les acquisitions de terres à grande échelle (ATAGE) sont devenues important dans le discours sur le développement. Les arguments en faveur et contre les ATAGE reflètent les impacts socio-économiques et environnementaux perçus alors que la terre, une ressource locale, est acquise pour la sécurité alimentaire, l'énergie, les investissements financiers et les crises environnementales mondiales. Les gouvernements des pays hôtes jouent un rôle essentiel dans la conception de paysages politiques pour enfermer les ressources des communautés locales pour l'accumulation de capital par des entités commerciales disposant de plus de ressources financières et d'un accès au pouvoir. Cependant, la mise en œuvre des accords ATAGE est ponctuée de cas d'annulation, de réduction d'échelle, d'abandon ou de changement de modèle économique d'investissement. Des études de cas ont mis en évidence l'échec de la mise en œuvre des accords ATAGE. Cependant, peu de tentatives ont été faites pour comprendre ce qui explique ces échecs et ce qui se passe lorsque la politique de l'État et la mise en œuvre des accords fonciers échouent. Prenant le bloc agricole de Nansanga, un accord LSLA dirigé par le gouvernement zambien en limbo de développement, cet article présente les résultats d'une étude qui visait à comprendre l'écologie politique de la production de tabac et de l'exploitation du manganèse comme des activités économiques opportunistes - en plein essor dans une zone qui était sous régime foncier coutumier mais converti pour la production de cultures vivrières. L'étude a été éclairée par des entretiens avec des intervenants clés. Dans l'ensemble, les résultats montrent que le rôle du gouvernement dans le développement de Nansanga a disparu; créant un vide de développement que la production de tabac et l'exploitation à ciel ouvert du manganèse ont comblé. Le tabac et l'exploitation minière, fortement extractifs qu'ils sont des ressources forestières, ont émergé comme des épées à double tranchant: l'augmentation des entrées financières et la création d'emplois d'une part, et, d'autre part, conduisant à la fuite de la main-d'œuvre de la production des cultures traditionnelles, de la déforestation et de la degradation des terres, de l'anomie et déracination dans certains cas, pendant que l'utilisation et des utilisateurs des terres sont (re) définis.

Mot-clés: Zambie, Nansanga, acquisitions foncières à grande échelle, écologie politique, tabac, manganese

\section{Resumen}

La adquisición de tierra a gran escala (ATGE) ha surgido como un tema político importante en el discurso del desarrollo. Los argumentos a favor y en contra de las ATGEs reflejan el impacto socioeconómico y ambiental que se percibe a medida que la tierra, un recurso local, se adquiere para la seguridad alimentaria, la energía, las inversiones financieras y las crisis ambientales globales. Los gobiernos de los países anfitriones desempeñan un papel fundamental en la ingeniería del conjunto de políticas para incluir los recursos de la comunidad local con el fin de acumular capital por parte de entidades comerciales con más recursos financieros y acceso al poder. La implementación de los acuerdos de ATGEs está marcada por casos de cancelación, reducción, abandono o cambio de modelos de negocios de inversión. Los estudios de caso han resaltado las ejecuciones fallidas de acuerdos de ATGE. Sin embargo, pocos han sido los intentos para comprender qué explica tales fallos y qué sucede cuando fracasan tanto la política estatal como la implementación de los acuerdos de tierras. Tomando el bloque agrícola de Nansanga, un acuerdo de ATGE en el limbo del desarrollo liderado por el gobierno de Zambia, este artículo presenta los resultados de un estudio que tuvo como objetivo comprender la ecología política de la producción de tabaco y la minería de manganeso como actividades económicas oportunistas; es decir, actividades que se benefician de la infraestructura existente de un proyecto gubernamental 'fallido' y de un área floreciente que estaba bajo tenencia tradicional pero que ha sido convertida a la producción de cultivos alimentarios. El estudio se basó en entrevistas a informantes clave con las partes interesadas. En general, los resultados muestran que el papel del gobierno en el desarrollo de Nansanga desapareció, creando un vacío de desarrollo que se ha llenado mediante la producción de tabaco y la minería de manganeso a cielo abierto. La industria tabaquera y la minería, muy extractivas de recursos forestales, aparecen como espadas de doble filo: aumentando los ingresos y la creación de empleo, por un lado; y, por el otro, provocando la huida de la mano de obra de obra de cultivos tradicionales, la deforestación y la tierra, así como la degradación, anomia y desarraigo en algunos casos a medida que se (re)definen el uso y los usuarios de la tierra.

Palabras clave: Zambia, Nansanga, adquisiciones de tierras a gran escala, ecología política, tabaco, manganeso 


\section{Introduction}

Managing, mediating, delivering, and producing the environment is a core and foundational feature of the modern, territorially defined, capitalist state. (Parenti, 2015, p. 830)

Large scale land acquisitions (LSLAs) have stirred contentious debates among different stakeholders. The arguments in support of and against LSLAs reflect the perceived socio-economic and environmental impacts when land, a local resource, is acquired by wealthier outsiders. Supporters of LSLAs claim they are addressing food security, energy needs, financial investments and global environmental crises (Borras and Franco 2012). Interest in the LSLA phenomenon has brought together scholars from different academic disciplines. Platforms such as the annual Land and Poverty Conference ${ }^{2}$ and research in journals ${ }^{3}$ have helped to elevate the profile of LSLAs in development policy discourses. Promoted on the assumption there is 'surplus land and surplus labor' in host countries, that both investors and states say needs to be exploited (Li 2011), the contemporary wave of LSLA is linked to neoliberal capitalism. It is assumed that capitalist interests are in search of new sources of accumulation (Baglioni and Gibbon 2013) 'in natural resource-rich but finance poor' countries (Chilombo et al. 2019). Development practitioners (e.g. the World Bank) and policy makers in host countries view LSLAs as a mechanism for development and the alleviation of rural poverty (see critiques by De Schutter 2011). To that end, governments in host countries continue to attract investments in land, partly on the basis of 'governance gaps' (Hall 2010; De Schutter 2011). Thus, governments play a critical role in the contemporary wave of LSLAs (for a historical review, see Roudart and Mazoyer, 2015).

Using their political legitimacy and economic capacity (Parenti 2015), governments in host countries craft policy and institutional frameworks to transfer land to producers perceived to be more efficient (Deininger and Byerlee 2012). When land is transferred, it is re-defined, re-assembled and given a new meaning (Li 2014) that sets new political and social processes and boundaries regarding how old users (community members) and new users (investors) will interact with it. Governments are, therefore powerful institutions in the different biophysical, political, economic and socio-cultural landscapes in which LSLAs unfold for capital accumulation. According to Parenti (2015 p.830), "managing, mediating, delivering, and producing the environment is a core and foundational feature of the modern, territorially defined, capitalist state." States, by action or inaction, define the identities of actors that bear the brunt of environmental degradation and the conflicts ensuing from their marginalization (Robbins 2012).

LSLAs are on the rise, as earlier commentators noted (Deininger and Byerlee 2012). Land changes hands and acquires new boundaries using fences, title deeds, laws, zoning, regulations, landmarks and storylines (see Li (2014. LSLA research has highlighted that the implementation of large land deals is punctuated with cancellations, scaling down, and the abandonment or change of investment business models (e.g. Locher and Sulle 2015; Hufe and Heuermann 2017; Schoneveld 2017). The academic literature on LSLA is largely negative (see Oya, 2013), partly because of challenges related to implementation of LSLA deals. However, few attempts have been made to understand what accounts for such failures in implementation and what happens when both state policy and the implementation of land deals fail. We studied the Nansanga farm block (Nansanga hereafter), a government of Zambia-led LSLA deal that has reached a limbo state of development. More specifically, we examined the political ecology of tobacco production and manganese mining that have emerged and flourished as opportunistic economic activities, that is, activities that have taking advantage of improved physical access and new land tenure status of an otherwise failed government project.

Nansanga was conceived as a public private partnership venture modelled on contract farming. It is part of the LSLA programs led by the 2002 government of Zambia to commercialize agriculture for food security, reduce rural-urban migration and rural development (GRZ 2005). The government's role has vanished in the

\footnotetext{
2 This is an annual event hosted by the World Bank Group in Washington DC. It is one of the largest international events on land governance, attracting participants from governments, academics, civil society, and the private sector.

${ }^{3}$ Such as Journal of Peasant Studies, Land Use Policy, Journal of Agrarian Change, and Journal of Political Ecology, among others.
} 
farm block program after converting 155 000 ha of land from customary tenure to leasehold, and after investing public resources to develop physical infrastructure, much of which has since collapsed. In this absence of development, tobacco production (by foreign-owned Tombwe Processing Limited) and two manganese mining companies (Kampoko and Jack Manganese owned by Zambians, not from Nansanga) have established operations and flourished, by exploiting land that under the LSLA policy was designated for commercial agriculture.

In this article, we seek to contribute to the understanding of the LSLA phenomenon by exposing the political ecology of an LSLA deal that has not advanced to a development phase. We attempt to answer the following questions: what accounts for the socio-environmental changes perceived by the local people in Nansanga as the government's role vanishes and paves the way for the flourishing of tobacco production and manganese mining in an area initially planned for food crop production? How are these changes distributed among stakeholders? By socio-environmental changes, we refer to the social aspects (culture, livelihoods, access to resources, local institutions for resource governance) changes in Nansanga coupled with environmental degradation in terms of deforestation and land degradation (see Ariza-Montobbio, Lele, Kallis, and Martinez-Alier 2010). An analytical approach was used that relied on participatory rural appraisal methods. By looking at the social and environmental changes occurring in an LSLA that has not advanced as planned, this article contributes to clarify the divided and ambivalent role of political ecology in environmental and social policy (Walker 2006) but also the politics of rural development modelled on public private partnerships.

The article is structured as follows: we first present the research design and methods in Section 2. In this section, we first lay the theoretical foundation by contextualizing political ecology within Zambia's politics of commercial agriculture. In Section 3, we provide empirical insights into the observed development on tobacco production and manganese open pit mining in Nansanga. We discuss these findings in Section 4, before concluding.

\section{Research design and methods}

We first highlight the context of political ecology within Zambia's politics of the farm block program, then present the study area, the participatory rural appraisal approaches that the lead author used for data collection, including the approach used to estimate woodfuel use in tobacco production.

\section{Contextualising political ecology within Zambia's politics of the farm block program}

We highlight the basic tenets of political ecology and its relevance to environmental and social changes attributed to the government of Zambia's failure to successfully establish a functional Nansanga. The LSLA deal saw the conversion of customary land to leasehold tenure, to pave the way for commercial agriculture. The government's failure created a development vacuum that tobacco production and manganese mining have filled with their extractive and destructive activities. While land appropriation for manganese mining has been through purchases from landowners in Nansanga, tobacco production has not involved any land purchases. It has used an out-grower production model but is dependent on high volumes of firewood, resulting in local deforestation.

Inherited from its colonial land administration, Zambia still has a bifurcated land tenure system: customary land under traditional authorities, and state land managed by the Commissioner of Lands at the Ministry of Lands on behalf of the President (Smith, 2004). In 2002 the General Republic of Zambia (GRZ) (then led by the Movement for Multiparty Democracy under the late president Levy Patrick Mwanawasa [2002 - 2008]) decreed the establishment of nine farm blocks across the country to expand commercial agriculture hoping to attain economic diversification and growth, to enhance national food security and for export, and to open up undeveloped rural areas, reduce poverty and minimize rural to urban migration (GRZ, 2005). This meant targeting customary land that was assumed to be abundant but idle and in dire need of development. In this 'logic of development', customary land is equivalent to a 'wasted opportunity, wasted resource' that must be transformed into a development opportunity. However, the size of customary land continues to shrink, amplifying its scarcity and competition as the Zambian population rises (Jayne, Chamberlin, \& Headey, 2014). At independence (1964), customary land stood at 94\%; and state land at 6\%. Some 45 years later, the World 
Bank (2009) estimated customary land to be $62 \%$ of the national territory. More recently Sitko and Chamberlin (2016) estimated it to be 51-54\%.

Given resource constraints, the implementation of the farm block program was in phases, and Nansanga was on the priority list. GRZ negotiated with the senior chief Muchinda of the Lala people in central Zambia. The chief surrendered $\sim 155,000$ ha of customary land to the government for conversion to leasehold. GRZ identified poor infrastructure in rural areas as a limiting factor in increasing attractiveness of agricultural investments. In the farm block program therefore, GRZ planned to construct roads, bridges, boreholes, schools, health facilities, and dams as well as pulling electricity into the farm blocks (GRZ, 2005).

The farm block program was modelled on contract farming where smallholders, medium and commercial farms produce crops to sell to an agri-business entity. This agri-business would then export crops to the sub-region and overseas (GRZ, 2005), linking producers to outside markets. It should be noted that investors for the venture were to be secured after the infrastructure and land tenure process had been completed, not before. Later, Bona Farm company from Hungary won the tender to invest in the core venture, driving the development of farms, including the crops to be produced and the links to markets. For other farm sizes, GRZ advertised the plots as farmland and people applied for them if they were interested and had the means to develop them. GRZ conducted interviews, and those who had viable business plans were allowed to buy the plots. By 2012, title deeds were processed and given to investors who had bought farmland in the farm block. With the exception of the above-mentioned core venture, the investors in farms were middle to high income Zambian individuals from urban areas.

While the late president Levy Patrick Mwanawasa made a strong economic case for improving agriculture (Cherry, 2002), subsequent governments by the Movement for Multiparty Democracy under Rupiah Banda (2008 - 2011) and the Patriotic Front under Michael Sata (2011 - 2014) and Edgar Lungu (2014 to date) have not showed meaningful economic and political interest in the agriculture sector, or the development of farm blocks.

To the extent that LSLAs do not happen in a policy and institutional vacuum, the government of Zambia (GRZ) was critical in shaping the Nansanga deal and its outcomes. In this regard, political ecology can help to provide a nuanced and necessary perspective on the relationship between the development project and the state (Wolford et al. 2013), and to examine the links between conflict and the use of rural resources that underpin rural livelihoods (Deligiannis 2012) for the Lala people whose customary land has been converted to leasehold. As it "seeks to understand how local resource use and perception are mediated by a combination of regional biophysical characteristics and processes, and the discursive-material manifestations of power that operate across geographic scales" (Offen 2004, p. 22), political ecology helps to understand meanings, definitions, and identities of rural resources and environment for community survival, that are culturally constructed (Wolford et al. 2013). This is particularly relevant to Nansanga where the conversion of 155,000 ha of customary land to leasehold created an enclave within the Lala Muchinda chiefdom.

The conversion of land tenure has de jure and de facto reshaped the socio-ecological system in Nansanga, including relations of power among actors. As political ecology seeks to understand and explain linkages in the condition and change of the social-environment nexus, with explicit consideration of relations of power among actors, land tenure conversion is a central process (Robbins 2012).

\section{Study area}

This study was carried out in Mingomba and Kabundi communities of the Nansanga farm block (henceforth as Nansanga) (12 $47^{\circ} \mathrm{S}$ to $13^{\circ} 0^{\prime} \mathrm{S}$ and $30^{\circ} 5^{\prime} \mathrm{E}$ to $30^{\circ} 4^{\prime} \mathrm{E}$, with elevation between $1,210 \mathrm{~m}$ and $1,347 \mathrm{~m}$ ), among Lala people of Senior Chief Muchinda in central Zambia. Mingomba and Kabundi are areas where tobacco production and (in Kabundi) mining are happening, with associated positive and negative socioeconomic impacts. Environmental degradation from tobacco production and mining are threatening local food production systems (Chilombo, 2019). Mingomba and Kabundi benefitted from infrastructure development from the Nansanga land program. The government planned to invest $\sim$ US\$11.4 million in the region to develop infrastructure: roads, dams, bridges, electricity and irrigation canals. But only $17 \%$ of that amount was actually invested between 2002 and 2006 (GRZ 2006). Commercial operators who bought land 
have not moved on site since 2012, and the government did not finish infrastructure development, including finding an enterprise to run the core venture of the farm block after the Hungarian company Bona Farm pulled out. Land buyers in Nansanga were issued with title deeds, as part of the farm block program.

At the time of this study, the infrastructure had already collapsed, and roads and demarcations were overgrown. The selection of Mingomba and Kabundi community areas for this study enabled an understanding of the emergence of tobacco production and mining, and how communities are experiencing them.

Based on the historical account of Nansanga by the Senior Chief Advisor, before settling in Mingomba, households were clustered together in Kanshinke village, to the north. Land was distributed according to local clans. In 1973 the government forced communities to settle near passable roads to facilitate extension services. However, lack of water, disputes over land and witchcraft forced people to return to Kanshinke. Years later, the Senior Chief Muchinda began allocating land to households again in Mingomba. Households were isolated from one another to lessen social conflicts experienced in the early 1970s.

Kabundi, on the other hand, was the first palace of Senior Chief Muchinda years before 1960. Because the palace was there, Kabundi was established as a sub-district when Serenje became the main district town in 1940. A health post, local court and school were established, rare as these were in those days. The Kabundi area also has the Kampumbu resettlement scheme, occupied mainly by the Tonga people from southern Zambia. Some of them are retirees, and others moved to the resettlement scheme as farmers. Therefore, compared to Mingomba, Kabundi has had more development programs, and is more culturally mixed. Nansanga lies within the third ecological zone of Zambia. With an annual rainfall of $\sim 1,200 \mathrm{~mm}$, it is characterized as a wet miombo woodland (Chidumayo 1987; Frost 1996).

Until the 1990s, the Lala people practiced shifting cultivation on customary land. Lala communities are mainly smallholder farmers, cultivating maize, cassava, groundnuts, and beans on 0.1-2 ha. A traditional Lala calendar has 13 months, and throughout the year, Lalas are involved in agriculture-related activities. The life of the Lalas therefore revolves around farming. The Tonga community within the resettlement scheme are more subsistent, and socio-economically wealthier than the local Lala people in Nansanga. Some Lala people are employed to work on the farms for the Tonga people.

\section{Participatory Rural Appraisal approaches for co-production of knowledge}

To understand the political ecology of tobacco production and manganese mining, participatory rural appraisal (PRA) methods were used. PRA methods are a convergence of a number of research programs that are commonly used in participatory action research, agroecosystem analysis, applied anthropology, and farming systems (Campbell 2001). According to Abbot (1996), PRA methods offer a platform for rural communities to present, share and analyze their knowledge of life and conditions. We employed mixed methods to gain insights into real-life contextual and multi-level perspectives, and cultural influences (Creswell et al., 2014). Our research was exploratory and explanatory, therefore mixed methods allowed us to understand 'how, why and what' questions. Also, our choice of mixed methods was motivated by the fact that the methods draw "upon the strengths of both quantitative and qualitative approaches and provides an innovative approach for addressing contemporary issues" (Fetters et al., 2013, p. 2135).

The choice of PRA methods for this study was based on three considerations: First, beyond the political and media rhetoric, evidence-based socio-economic and environmental assessments of the establishment of the farm block in the context of the contemporary LSLAs in Zambia are scanty. Second, the research was carried out in the area where an LSLA deal is unfolding. Therefore, the PRA methods engaged community members who have been impacted by the LSLA deal and knew of the political ecology of tobacco production and manganese mining. Finally, this was a qualitative case study, and therefore, we were concerned with data richness (see Higginbottom 2004), trading breadth for depth (see Murphy et al. 1998). 


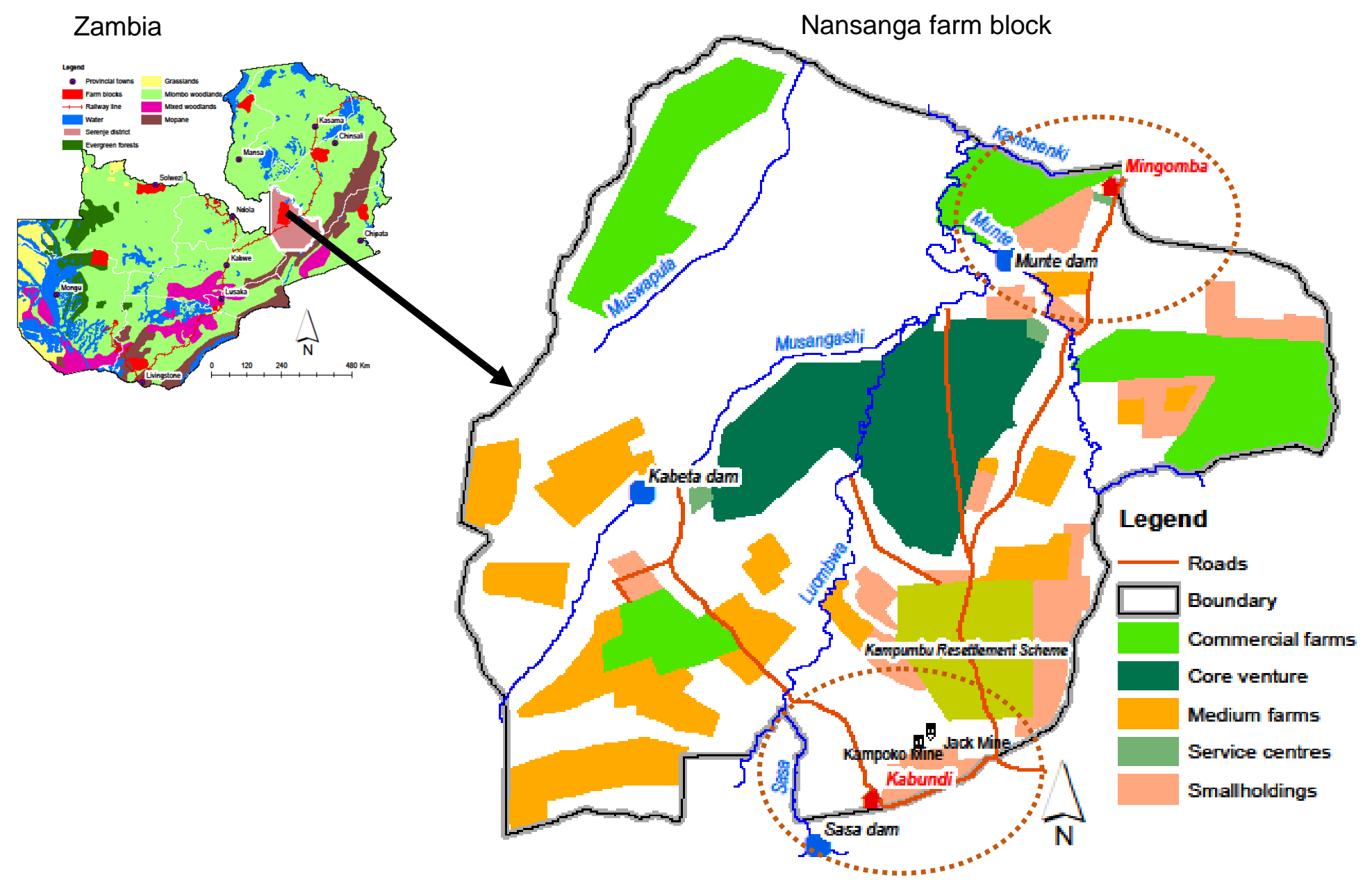

Figure 1: Study sites, Mingomba and Kabundi community areas. Author's creation based on GRZ (2005) and Ryan et al. (2016); data from httn://www.diva-gis.nrg/gdata (acressed Sentemher 5. 2018). 
With a lack of information about Nansanga justifying PRA methods, we interacted directly with local residents (Campbell 2001). PRA methods enabled the involvement of Nansanga community members as 'coproducers' of knowledge about LSLAs; giving them the opportunity to reflect and draw meaning from their lived experiences. In the next section we detail the PRA methods that we used to understand the political ecology of tobacco production and manganese mining in Nansanga.

With the support of traditional leaders, the Sulutanis and Chilolos (village headmen and Senior Chief Advisors, respectively), groups of community members were convened in different areas for focus group discussions (FGDs) ( $n=13$ in each of the community areas, that is, Mingomba and Kabundi) on the impacts of establishing the farm block in the Muchinda chiefdom. FGDs comprised eight to nine people, men and women. The rationale for contacting the Sulutanis and Chilolos was twofold: to respect the culture of the Lalas that instruct that visitors enter the chiefdom through the traditional authorities; and Sulutanis and Chilolos are 'community parents' who know all community members by their names, homesteads, and socioeconomic conditions. According to Kitzinger (1995, p. 299), "focus groups are a form of group interviews that capitalises on communication between research participants in order to generate data." With a questionnaire guide, the lead author brought up topics of relevance (Calder 1977) to facilitate the understanding of the emergence of tobacco production and mining in Muchinda chiefdom. As DiCicco-Bloom and Crabtree (2006) suggest, there was flexibility in following the planned topics to explore community members' interests, knowledge and themes as they emerged during the discussions. FGDs revealed community-level perceptions and lived experiences of tobacco production and mining beyond the experiences of individual tobacco producers and mine workers. Thus, FGDs supported the understanding of the collective but diverse and divergent perceptions and opinions about LSLAs and their effects on the livelihoods of rural communities beyond those of individuals (Chandra 2010). In this way, FGDs helped to check expert opinions from key informants (Morgan 2008). FGDs triangulated the data that was collected from key informants.

Through snowball sampling, the Sulutanis and Chilolos supported the identification of key informants ( $\mathrm{n}=21$ in Kabundi, and $\mathrm{n}=21$ in Mingomba. These include 17 tobacco producers - see the section on woodfuel consumption below). Snowball sampling offered practical advantages for gathering data about a difficult-toobserve phenomenon (Faugier and Sargeant 1997). The key selection criteria were the interviewees' involvement in producing tobacco, employment in the manganese mines, and their participation in activities during the demarcation of land parcels. Another consideration included the community respect commanded by individuals, as this benchmarked their credibility as informants. Within the chiefdom, the mix of FGDs and key informants enabled "greater depth from the latter and greater breadth from the former (Morgan $2008 \mathrm{p}$. 134)."

Outside the farm block, by the same snowball sampling technique, key informant interviews were conducted with government and quasi-government institutions, researchers, agri-business entities, civil society organizations and development practitioners $(n=18)$. It is through snowball sampling that knowledgeable interviewees were efficiently identified (Faugier and Sargeant 1997; Kendall et al., 2008). Outside Nansanga, the Ministry of Agriculture was approached first. During an interview, we were referred to two departments at the Ministry of Lands for additional information. The Ministry of Lands referred us to the Zambia Development Agency, then the Zambia Environmental Management Agency, then the Departments of Resettlement and Disaster Management at the Office of the Vice President. This process occurred with other relevant stakeholders.

\section{Estimation of woodfuel consumption in tobacco production}

Using snowball sampling, and with the support of the Sulutanis and Chilolos, a total of 17 tobacco producing households in Mingomba $(n=10)$ and Kabundi $(n=7)$ were identified and interviewed using a structured questionnaire. We sought to understand the motivations for producing tobacco. Growers were also asked about the socio-economic benefits and concerns of tobacco farming, labor demands, amount of land under tobacco farming, the quantity of wood used for tobacco curing, production methods and deforestation related to tobacco production. The farmers are in contractual production arrangements with Tombwe Processing Limited (TPL), a tobacco leaf company with a national office in Lusaka, Zambia. TPL distributes inputs and offers training to its farmers in Nansanga, buying the crop mainly for export to China. 
To estimate woodfuel consumption from tobacco production, the lead author used the weighing method, (see Brouwer and Falcão 2004; FAO and UNHCR 2017; Fox 1984). In estimating woodfuel consumption, we sought to understand the environmental impacts of tobacco production and their distribution. Individual logs in a bundle were weighed on an analog hanging scale, then multiplied by the total number of bundles used by the farmer to cure tobacco in one growing season. The practice is that woodfuel is heaped in bundles called ifikoto of $\sim 2 \mathrm{~m} \times 1.5 \mathrm{~m} \times 1 \mathrm{~m}$. Firewood collected during land preparation was weighed separately from the freshly cut timber. The average was then calculated and recorded. Weighing in this way is reported as accurate (Fox 1984) and convenient for irregularly shaped logs.

\begin{tabular}{|c|c|c|c|c|c|c|}
\hline \multirow{2}{*}{ Fieldwork } & \multicolumn{3}{|c|}{$\begin{array}{l}\text { Focus Group Discussions } \\
\text { (FGD) }\end{array}$} & \multicolumn{3}{|c|}{ Key Informant Interviews (KII) } \\
\hline & Kabundi & Mingomb & & Kabundi & Mingomba & $\begin{array}{l}\text { Outside } \\
\text { Nansanga }\end{array}$ \\
\hline Total & 13 & 13 & & 20 & 21 & 18 \\
\hline \multicolumn{7}{|c|}{ Anonymised identities of interviewees and their description } \\
\hline \multicolumn{3}{|c|}{\begin{tabular}{l|l} 
Identity code & L
\end{tabular}} & \multicolumn{4}{|c|}{ Description } \\
\hline \multicolumn{3}{|c|}{$\begin{array}{l}\text { M-KII (Mingombo KII) } \\
\text { M-FGD (Mingomba FGD) } \\
\text { K-KII (Kabundi KII) } \\
\text { K-FGD (Kabundi FGD) }\end{array}$} & \multicolumn{4}{|c|}{$\begin{array}{l}\text { Community members in Mingomba and Kabundi } \\
\text { community areas fulfilling sampling criteria }\end{array}$} \\
\hline \multicolumn{3}{|c|}{ LT-KII } & \multicolumn{4}{|c|}{$\begin{array}{l}\text { Key informants working for the leaf tobacco company, } \\
\text { Tombwe Processing Limited. }\end{array}$} \\
\hline \multicolumn{3}{|l|}{ TF-KII } & \multicolumn{4}{|c|}{ Key informants who are tobacco growers in Nansanga. } \\
\hline \multicolumn{3}{|l|}{ Mm-KII } & \multicolumn{4}{|c|}{$\begin{array}{l}\text { Key informants working for the manganese open pit mines } \\
\text { in Nansanga. }\end{array}$} \\
\hline \multicolumn{3}{|l|}{ Inv-KII } & \multicolumn{4}{|c|}{$\begin{array}{l}\text { Respondents who have invested in Nansanga and outside } \\
\text { Nansanga through purchase of what was previously held } \\
\text { customary land. }\end{array}$} \\
\hline \multicolumn{3}{|l|}{ G-KII } & \multicolumn{4}{|c|}{$\begin{array}{l}\text { Key informants who are government officials working in } \\
\text { government departments that were part of the multi- } \\
\text { sectoral sub-committee to establish the farm block } \\
\text { program, including negotiating with the Senior Chief } \\
\text { Muchinda in Nansanga. }\end{array}$} \\
\hline \multicolumn{3}{|l|}{ Qg-KII } & \multicolumn{4}{|c|}{$\begin{array}{l}\text { Key informants involved in promoting investments in } \\
\text { Zambia, and or in ensuring the compliance of the } \\
\text { implementation of LSLA deals in the country. }\end{array}$} \\
\hline \multicolumn{3}{|l|}{ C-KII } & \multicolumn{4}{|c|}{$\begin{array}{l}\text { Civil society organizations, key informants involved in } \\
\text { land policy formulation, and work with communities in } \\
\text { rural areas that are on customary land. }\end{array}$} \\
\hline
\end{tabular}

Table 2: Overview and coding of research participants.

\section{Results}

As background, we first present the history of the Nansanga development scheme to show how it came about, and how and why its development has not advanced. We present results on tobacco production and 
manganese open pit mining. We also highlight the socio-economic and environmental impacts ensuing from these two flourishing activities in Nansanga on what was once customary land farmed for food crops.

\section{Nansanga as a 'failed' LSLA deal}

As in many African countries, commercial agriculture is still the dominant policy mantra for rural development in Zambia, particularly in state policymaking circles. Unfortunately, LSLAs for commercial agriculture have a poor track record in the effective delivery of rural development. LSLA deals generally remove smallholders and peasant farmers from ancestral and customary land, while seeking from them a casual workforce to assist capital accumulation by non-local owner interests (e.g see Hakizimana et al., 2017; McMichael, 2012). The frequent implementation failures of LSLAs support the critiques made by their opponents: namely that outside LSLA investors are engaged in capital accumulation through dispossession (of land) and externalization (of negative environmental and social impacts).

Interviews (D-KII \#1, G-KII \#3, C-KII \#2, Lusaka, December 2017) revealed that Bona Farm perceived there to be political risks in investing in Nansanga. This was to do with national politics: the Patriotic Front did not share the same agricultural ambitions with the Movement for Multiparty Democracy under Mr. Mwanawasa. Additionally, there were allegations of corruption in the selection of this investor. This explains why the second or third bidders for the same tender did not take up the core venture after Bona Farm pulled out (D-KII \#1, G-KII \#2, C-KII \#2, Lusaka, December 2017). Once customary land is converted to leasehold, at the end of the lease, the land becomes state land. There is no legal provision in Zambia to revert land to its previous tenurial status. This has fueled accusations that failed LSLA deals are actually a government mechanism through which customary land is expropriated from communities (C-KII \#3, Lusaka, November 2017).

The findings suggest that corruption and self-serving political party interests prevented a transparent process for the selection of the most viable agri-business entity, leading to the failure of Nansanga. They also led to the failure of government commitments to complete infrastructure and other investment on the farm block, by limiting the financial resources needed to complete the works (only $17 \%$ of the total budget was spent on infrastructure development). Dams collapsed, irrigation channels failed, and the out growers scheme failed to thrive as land parcels became overgrown. At the time of the fieldwork, GRZ was not 'courting' agri-business to further develop Nansanga. Private investment had all but ceased. Tobacco and mining companies did not buy land from GRZ during the establishment of Nansanga, and therefore did not start operating as part of the farm block program. However, as their operations grew in Nansanga, some community members did well while others lost out. The following socioeconomic and environmental conditions emerged:

1. Land titling of previous customary land created land markets on which manganese mining is flourishing. Landowners, particularly those faced with financial difficulties, are selling their land to the companies to continue their mining activities. While this is cushioning the socioeconomic situation of some landowners, it is slowly creating a class of landless people whose livelihoods are tied to the exploitation of land and associated resources;

2. Tobacco leaf and manganese mining companies are riding on the road infrastructure that GRZ had built for the farm block program. They have also created financial incentives for the employment of cheap, casual local labor in a local economy that was largely cashless. The financial incentive is pulling the active population from food crop production. Nonlocals are holding more of the managerial positions in the companies;

3. While the process of establishing Nansanga was led by the Ministry of Agriculture, manganese mining has been supported by the Ministry of Mines who issued the mining licenses - without the official knowledge of the Ministry of Agriculture (G-KII \#1, Serenje, December 2016) or the Zambia Environmental Management Agency (Qg-KII \#1, Lusaka, April 2018);

4. Tobacco leaf and manganese mining are both resource-extractive activities carried out by non-Lalas. Environmental changes such as land cover change, depletion of soil fertility, land 
degradation and deforestation disproportionately impact the Lala people who almost entirely depend on the exploitation of land for their livelihoods; and

5. Overall, even if a 'win-win-win situation' according to the original government plan for the area is absent, tobacco production and manganese mining have partially contributed to some of the farm block development objectives.

Additional information for both tobacco production and manganese mining is presented below.

\section{Tobacco production}

Tobacco is produced in written down and signed contractual agreements with TPL. Lala producers grow tobacco on land allocated by traditional authorities, and non-Lalas grow it on their titled land that they bought. Farmers are organized in cooperatives through which TPL provides technical knowledge on the best practices for growing, picking and curing high grade tobacco that earns more money for both parties.

Though TPL could not disclose the number of farmers producing Virginia tobacco, the number is increasing, with the following emerging: (1) growers are buying standing trees for woodfuel from non-growers; (2) migration to other production sites in search of more woodfuel; (3) some are either giving up tobacco production, or suspending its production in search of alternative sources of woodfuel. Points 1 and 2 are associated with Lala people within the farm block, while point 3 is more associated with non-Lala who have recently settled in Nansanga (LT-KII \# 3, Nansanga, April 2018).

According to local accounts, tobacco production is associated with affluence for two reasons: (1) TPL only enrols into tobacco cooperatives households with potential to repay their loans; and (2) tobacco is laborintensive and therefore, the grower needs to have the means to hire additional labor beyond what the family is able to provide (TF-KII \#2 \& LT-KII \#3, Nansanga, March 2018). Table 2 details the profile of tobacco farmers in Nansanga.

\begin{tabular}{|c|c|c|}
\hline Details & Mingomba & Kabundi \\
\hline Profit range & Between US\$935 and US\$9,800 & Between US\$300 and US\$4,700 \\
\hline Number of farmers & $\begin{array}{l}\text { From an initial } 30 \text { to } 131 \text { (2015-2018 } \\
\text { growing season) }\end{array}$ & $\begin{array}{l}\text { From an initial } 4 \text { to } 91 \text { (2015-2018 } \\
\text { growing season) }\end{array}$ \\
\hline Land under tobacco & 250ha (2015-2018 growing season) & 60ha (2015-2018 growing season) \\
\hline Average production & $1,500 \mathrm{~kg} / 0.5 \mathrm{ha}$ & $1,500 \mathrm{~kg} / 0.5 \mathrm{ha}$ \\
\hline Loan compliance & 100 percent & 100 percent \\
\hline $\begin{array}{l}\text { Contractual } \\
\text { arrangements }\end{array}$ & $\begin{array}{l}\text { Out-grower scheme with signed } \\
\text { contracts with TPL }\end{array}$ & $\begin{array}{l}\text { Out-grower scheme with signed } \\
\text { contracts with TPL }\end{array}$ \\
\hline Production system & $\begin{array}{l}\text { Crop rotation, cultivation with hoes } \\
\text { using casual labor force. }\end{array}$ & $\begin{array}{l}\text { Crop rotation, cultivation with hoes } \\
\text { using casual labor force. }\end{array}$ \\
\hline
\end{tabular}

Table 2: Profile of tobacco farmers in Nansanga over three growing seasons (2015/20162018/2019).

Tobacco farms start closer to the houses and barns, and then continue expanding outwards for two reasons: 1) to reduce labor and carrying time during harvesting from the farm to the barns; and 2) during the curing period (February-March) it is easier to watch over tobacco on the farms and in the barns during the day and night (see Figure 2). 


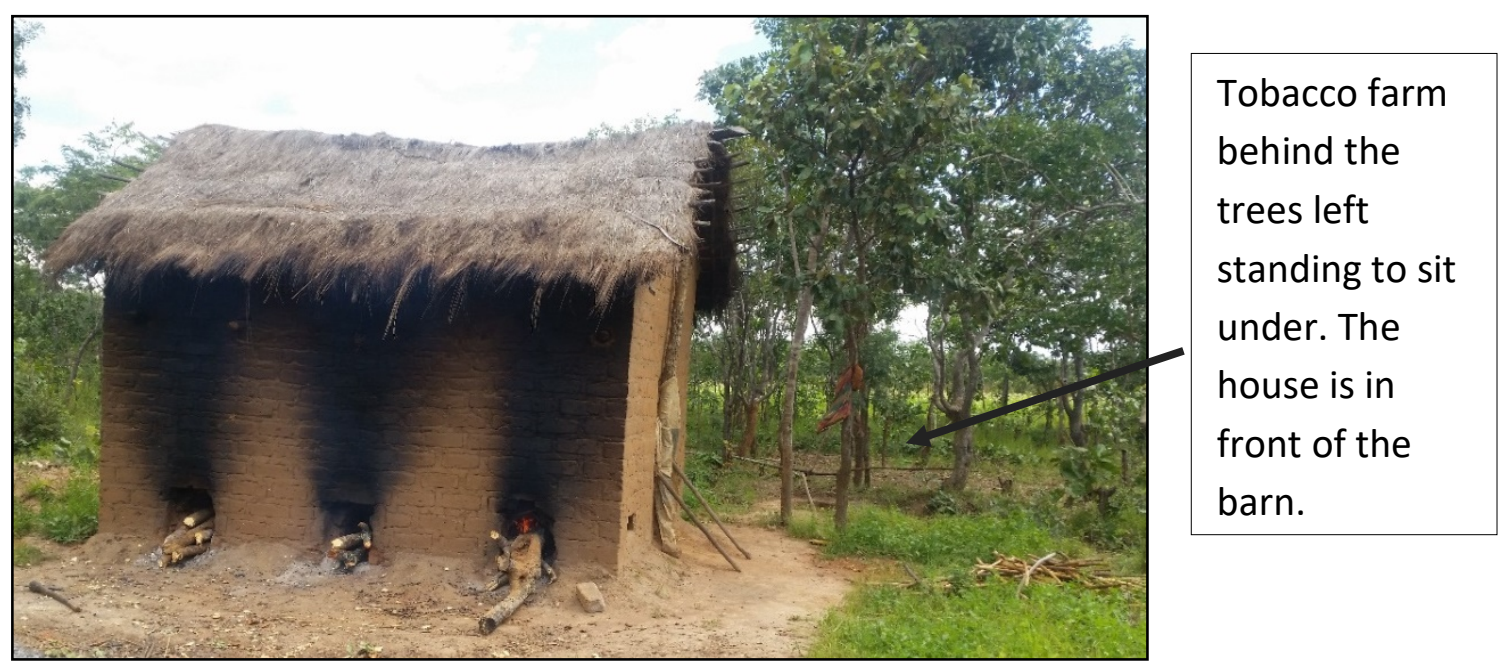

Figure 2: A typical barn for curing tobacco in Nansanga. (Picture: first author, Nansanga, March 2018).

Primary woodfuel that is used comes from cleared land for planting tobacco. The barns were of different sizes, generally measuring about 3.5m x 3m x 3m (Figure 2 above). Tobacco production is currently the leading cause of localized deforestation and land degradation in the area (TF-KII \#3, M-FGD \#3 \& researcher observation, Nansanga, March 2018).

In Mingomba the average estimated woodfuel consumption is 53 tons year ${ }^{-1}$, average size of farms is 0.8ha, and the number of barns is three per tobacco producing household. In Kabundi, average woodfuel consumption is 35 tons year ${ }^{-1}$, average size of farms is 0.5 ha, and there are two barns on average (Figure 3 ).

The tobacco production profiles for Mingomba and Kabundi are different. This can be attributed to the development trajectories of the two community areas. First, there is a Kampumbu resettlement scheme in Kabundi community area that is dominated by the Tonga people from southern Zambia who are pastoralists. Mingomba area only has Lalas who depend on the production of food crops on 0.1-2 ha. Second, manganese mining, offering casual jobs to people from within and from outside Nansanga, is in Kabundi. Therefore, Kabundi has alternative economic activities that do not depend on tobacco production. In addition, tobacco farms for non-Lalas (as in Kabundi with non-Lala migrants) are generally smaller because non-Lalas grow tobacco either on their titled land (which is smaller in size compared to customary land occupied by Lalas) or on rented land, which also tends to be comparatively small.

Trees for curing tobacco are cut at knee height. Trees with branches $>15 \mathrm{~cm}$ in diameter are cut at about $5-10 \mathrm{~cm}$ from the main trunk. This way of cutting is inherited from the cultural practice of the shifting slash and burn farming system (locally known as chitemene). This involves coppicing rather than felling trees (TFKII \# 8, Nansanga, March 2018). The only tree that is not often cut for tobacco curing is Erythrophleum africanum, locally known as Akayimbi because it is has extremely hard timber and is therefore difficult to cut down. 


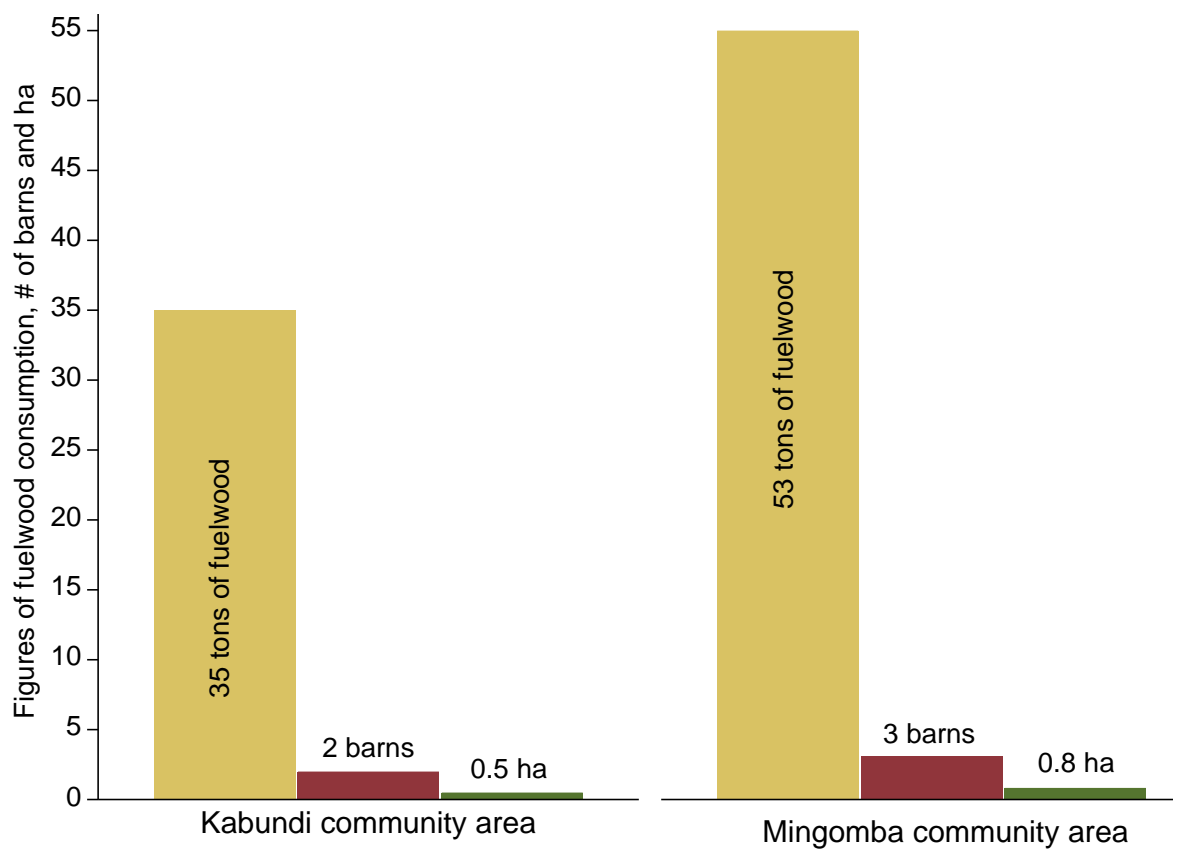

Figure 3: Average woodfuel consumption, \# of barns and hectares per community.

Unequivocally, farmers reported their reasons for producing tobacco were a to lack of government support with agricultural inputs, and poor marketing systems for maize, including delayed payments and lack of extension services. As an example, farmers cited the outbreak of armyworms, Pseudaletia unipuncta, during the growing season 2017-2018 for which they did not get any extension service support from the government. They also cited the failure of the e-voucher system for delivering agricultural inputs. ${ }^{4}$ On the other hand, TPL provides farmers with tobacco inputs, training, and pays them without delays. Additionally, farmers are provided with backpack sprayers and protective clothing, receive $10 \mathrm{~kg}$ of hybrid maize seed and $1 \mathrm{x} 50 \mathrm{~kg}$ bag of basal dressing and 1 x $50 \mathrm{~kg}$ of top-dressing fertilizers for every 0.5 ha of tobacco cultivated to avert the food insecurity of tobacco producing households. Maize inputs are freely given in the second year of the contract. Farmers also reported that tobacco has significantly higher returns than maize. For example, a 0.5 ha of highquality maize gives a profit of $\sim$ US $\$ 300$. Growing tobacco on the same size of land can earn a farmer $\sim$ US\$4,700, 15 times more (TF-KII \#6 \& LT-KII \#1, Nansanga, March 2018). Based on reported estimates, revenues from 0.5 ha of tobacco is almost three quarters of the annual salary of a postgraduate civil servant in Zambia.

Tobacco farmers have a 3 to 4 -year crop rotation in the following order: virgin land is cleared and planted to tobacco in year 1. Maize is planted in year 2 for the crop to benefit from tobacco fertilizer residue. In year 3 beans, soya beans or sweet potatoes, and in some cases, cassava are planted. In year 4 tobacco is planted again. In between, new frontiers of land are cleared for tobacco production and woodfuel. That is, farmers growing on 0.25 ha and those on 0.5 ha, with a 4-year rotation, clear 1 ha and 2 ha of land, respectively every 4 years to primarily produce tobacco. This excludes trees that are felled for additional woodfuel for curing. TPL reported the promotion of planting trees such as Sesbania sesban among its farmers. Interviews and researcher's observations did not confirm any tree planting programs in Nansanga.

\footnotetext{
${ }^{4}$ The Government of Zambia's agriculture sector reform to improve the delivery of inputs to farmers, giving them a chance to access inputs of their choice based on their needs. This is part of the Farmer Input Support Program
} 


\section{Manganese open pit mining in Nansanga}

The Kampoko and Jack manganese open mines were in operation in the Kabundi area when fieldwork was conducted from March-June 2018. Geologically, Nansanga sits on near-surface manganese deposits where open pit mining is the preferred method of extraction (Mm-KII \#2, Nansanga, March 2018). The mining companies buy titled land from landowners on a 'willing seller, willing buyer' basis (Mm-KII \#2, Nansanga, March 2018), and this is set to continue as they expand their operations in Nansanga. For those living and farming on customary land where the mining operations are encroaching, they are also negotiating with the companies to be paid and then to relocate (K-FGD \#4, Nansanga, March 2018).

The mines offer casual jobs. The requirements are simple: willingness to work, and being energetic. Those who meet these minimum requirements get registered (Mm-KII \#3, Nansanga, March 2018). No official contracts were reported during the interviews. At Kampoko mine, workers manually select manganese from heaps of stones that have been dug out by company machinery. At Jack mine, land is cleared by the company using their machinery, and workers then dig the ground with pickaxes and shovels.

At Kampoko mine employees receive K30 ( US\$2.72) for a 1-ton heap of manganese. At Jack mine, workers receive K25 ( US\$2.27) for the same quantity. Thus, those who produce 3 tons and are able to work for about 20 days in a month, receive $\sim \mathrm{K} 1,800$ ( US\$163.20) and K1,500 ( US\$136.20) if employed at Kampoko and Jack mines, respectively (Figure 4 picture 2). Interviews with employees revealed the following:

- The payment from manganese is far better than from the farms of white farmers in the neighboring Luombwa farm block;

- Traditionally, the Lalas are a matrilineal and an uxorilocal society (i.e. the husband goes to live with the wife's community) and women are socio-culturally empowered. From Kabundi area and surrounding villages, more married women work in the mines than married men. Men remain working on farms while their wives work in the mines. The reason is that women among the Lala people are independent and can control family finances because no dowry is paid on marriage. Men remain continue to farm with little access to money. This is in contrast to studies elsewhere that have reported men favoring more lucrative economic activities (see for example Jumbe et al. 2009; Kalaba et al. 2013; Katz-Lavigne 2016).

- Most male employees at the mining companies are those that have travelled from outside Nansanga, or unmarried men from different parts of Nansanga;

- There is nonethless labor flight from farming to mining in the following ways: the strong ones are opting to work in the mines, leaving the weak and aged to work on the farms. Revenue from mining is often spent on clothes or beer, particularly among male employees. This has raised concerns over food security in the area; and

- $\quad$ Some people have profited from working in the mines to improve their socio-economic situations - building better houses, buying bicycles and sending children to schools (K-FGDs \#4, Mm-KII \#3 Nansanga, April 2018).

The possibilities offered by mining in Kabundi area have also attracted an international and urban workforce, including young people from other parts of Muchinda chiefdom. Some come from as far as Lusaka, Zambia's capital almost 500km away, to do small scale businesses e.g selling clothes, kitchen utensils and bicycles. Truckers from Tanzania come to transport manganese from Kabundi. Local people are sometimes employed to sell items for businesspeople coming from outside Nansanga. Mine workers also provide markets for small baking businesses such as making fritters, and the local brew, called umunkoyo made from Rhyncosia spp roots and maize (Figure 5). Registered employees in the mines can buy on credit, in advance of their end of month salaries. 


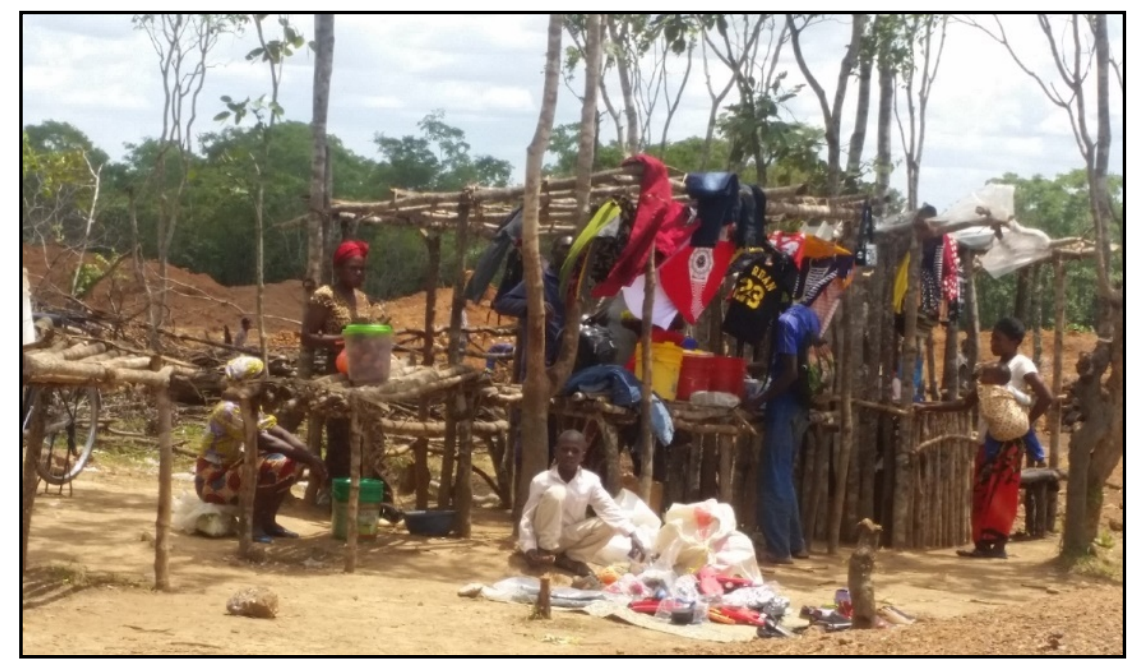

Figure 5: Small businesses at Jack mine. (Picture by corresponding author, Nansanga, March 2018)

Kabundi therefore, has become a hub of socio-economic activities around manganese mining. An interview with a health professional at Kabundi clinic revealed that with the arrival of people from outside the area, the clinic has been recording an exponential increase in sexually transmitted infections. The Sulutani of Kabundi also revealed that he has been receiving an increased number of marital-related disputes attributed to the fast-changing socio-economic dynamics in the area. Tobacco production and manganese mining reveal positive as well as negative outcomes in Nansanga. That is, in the absence of a 'win-win-win situation' according to the original plan for the area, the emergence of tobacco production and manganese mining contributes only partially to the realization of objectives laid down for the original farm block program. We discuss this further in Section 4.

\section{Discussion}

Our discussion focuses on the general implications resulting from the state in 'remaking' customary land into leasehold, and how this has led to new local community-resource relations characteristic of capitalist commodity relations. We then discuss tobacco production and manganese mining in three parts.

The state's 'remaking' of customary land (said to be idle) has enclaved it within the Muchinda chiefdom. This process has commodified it for capital accumulation by non-Lalas, including the erasure of solidified and regimented cultural practices with which the Lalas are identified as a people. This 'development by dispossession' (see Makki \& Geisler, 2011) goes beyond the appropriation of previously-held customary land for capital accumulation by the tobacco and manganese mining companies. The process of 'remaking' customary land, the vanished role of the state in Nansanga and the flourishing of external companies have cumulatively contributed to the 'marxization' of the most active local population as wage laborers. Land development by dispossession in Nansanga has resonances in Ethiopia where the state makes available 'underutilized', 'unused' or 'idle' land to domestic and foreign investors (Moreda, 2017), advancing the "terra nullius narrative of supposedly unproductive and empty spaces that need to be made productive through agribusiness investments" (Makki \& Geisler, 2011 p.11). LSLAs in Ethiopia are in lowland communities, underlying the state's target to weaken land rights and livelihoods of indigenous ethnic minority groups, and to expand federal authority and control over territory and people (Moreda, 2017). In Zambia, LSLA deals do not target specific regions, and do not appear to be marginalizing particular ethnic groups. They are taking place right across the country. For example, the farm block program targeted $\sim 967,750$ ha across the country (see Figure 1). 


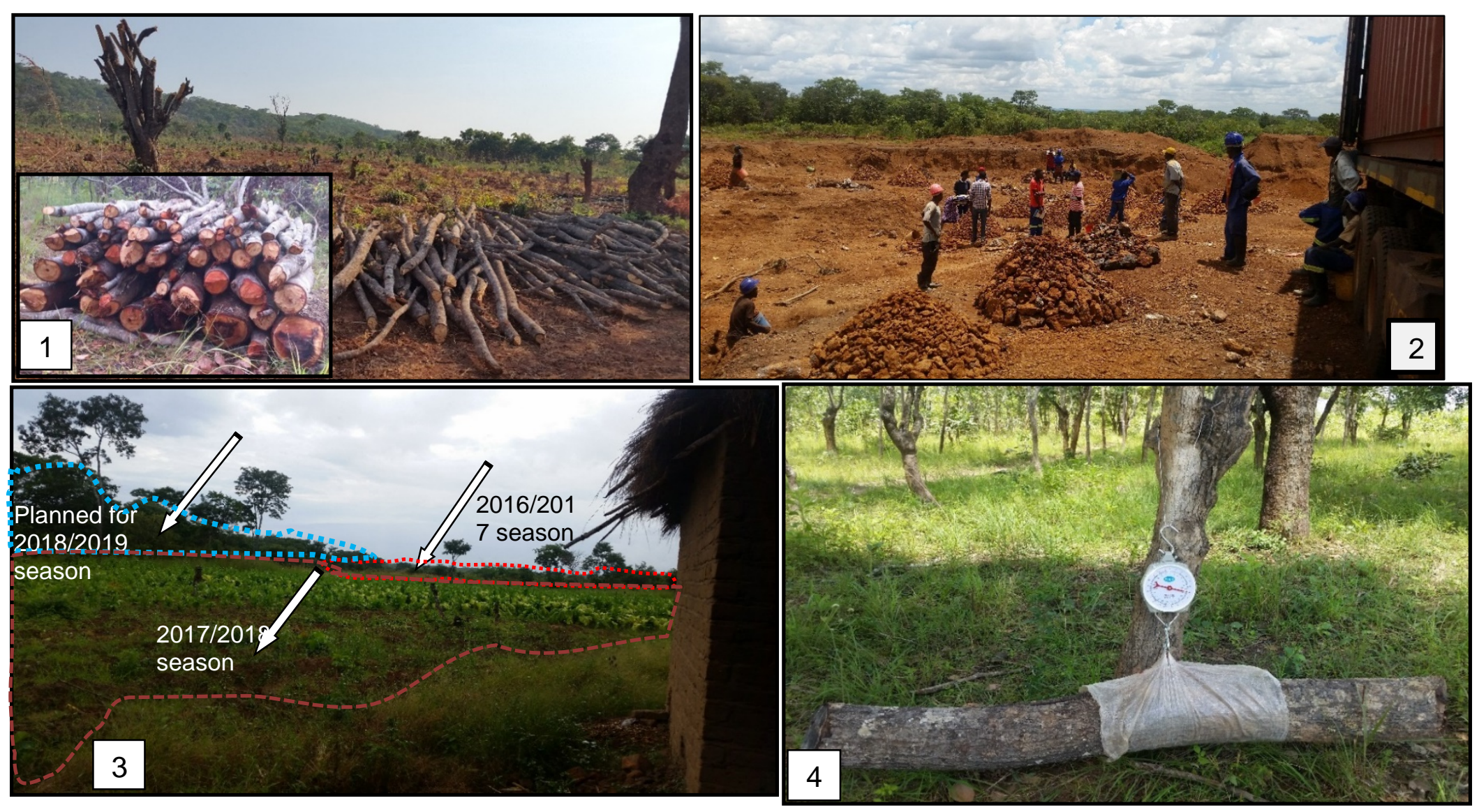

Figure 4: Tobacco production and mining in Nansanga. Picture 1: Land clearing for tobacco production at the foot of Kalonga hills in Nansanga, with fuelwood cut during land clearing to be used in February-March for tobacco curing and domestic use (this is a return to the same plot after 3 years [TF-KII \#13, Nansanga, March 2018]). The insert is a typical bundle, icikoto, of additional fuelwood for tobacco curing. Picture 2: Casual workers at Jack manganese open pit mine with a Tanzanian truck loading manganese. Picture 3: Seasonal rotation and frontier expansion for tobacco cultivation, and proximity of the farms to the kiln to ease transportation (TF-KII \#3, Nansanga, March 2018). Picture 4: Estimating fuelwood consumption by weighing individual logs (Pictures by corresponding author in Nansanga, 2017 - 2018). 
The Nansanga farm block case has resonance with other business investment models found in LSLA deals - downscaling, cancelation, abandonment or transformation. Commonly, land is under-utilized, degraded or converted for other purposes. As Locher and Sulle (2015) indicate, when LSLA projects fail, investors abandon projects or transform their investment models. In Ghana, failed jatropha LSLA deals have been transformed into rice production or replaced by other crops, or even solar energy production (Ahmed et al. 2017; Antwi-Bediako 2018). In Madagascar, after civil unrest, the Daewoo Logistics maize and palm oil project was canceled (Cotula et al. 2009). In Ethiopia, citing the unsuitability of land, investors abandoned areas after clearing forest for timber sales and charcoal production, contrary to contracted plans (Moreda 2017). In Mozambique, Fingermann (2015) attributes the failure of the ProSavana program to unreconciled political interests and expectations between the Brazilian, Japanese and the Mozambican governments.

Finally, while Nansanga farm block is unquestionably in limbo and the (planned) development has not gone ahead, the infrastructure that was developed at the start of the farm block's development, particularly roads, have provided important support for the emergence of mining and tobacco production. This has been at minimal cost to the companies involved. In this regard, initial development of the farm block is a backbone on which tobacco production and mining as economic activities have flourished, opportunistically. Tobacco production and open pit mining have short- and long-term impacts, including obvious environmental effects (e.g deforestation, land degradation, chemical application). Power dynamics are altered (e.g users of customary land vs companies with financial power), alongside social impacts (e.g landlessness, displacement, food insecurity). As these activities continue, local food production and livelihoods and socio-political organization are being disrupted while resource and labor scarcities increase - all embedded in institutionalized and powerladen land management, access and use (Robbins 2012). Based on the interviews and observations of tobacco producers and employees in the two mines, there are also positive short-term economic - particularly the growing (cash) income opportunities from tobacco farming and manganese mining. However, these opportunities are going hand in hand with increased levels of resource degradation; tobacco consumes the trees around it and manganese consumes the land above it. The associated growth in landlessness fuels growing inequalities while the mining companies continue to benefit, taking advantage of available cheap labor.

While contract tobacco farming has flourished, manganese mining has emerged using a different production model. At the time of fieldwork, mining was being done on titled land which the mining companies had bought from landowners who had themselves purchased it during the establishment of Nansanga. In many cases, the first private owners held the land without improving productivity (as was the formal purpose of leasing the land under the farm block policy). There was thus a speculative aspect to their purchase and the subsequent sale benefited both the absentee landowners (who saw land value rise without having to make any effort) and the mining companies (who need land to be privatized so they can buy it, but also who are happy to buy it cheaply if it is un-developed). Besides land appropriation, mining has benefitted not only from cheap land for sale, but also from abundant cheap labor from both Lalas and non-Lalas who have migrated to the chiefdom from other villages and towns.

The purchase of land from landowners in Nansanga farm block did not involve the Ministry of Lands. The mining companies dealt directly with landowners (Mm-KII \# 2, Nansanga, March 2018). In this way, the transaction costs were minimal. As open pit manganese mining continues in the area, so will the selling of land, and households on customary land will be resettled to have the land tenure converted for mining operations. This means the process of moving land from customary tenure into private hands is likely to continue until mining prospects in the Kabundi area diminish. In this particular case, the mining companies directly interact with community members who are willing to sell, since they know it will be a matter of time before they lose it to the companies anyway (K-FDG \#4, Nansanga, March 2018). We now provide more information on the political ecology of tobacco production and manganese mining.

\section{The political ecology of tobacco production in Nansanga}

GRZ's failure to successfully implement the farm block program has boosted tobacco production, and this has reportedly improved the socio-economic situation of those growing it (in the short term), and indirectly 
benefited others through provision of seasonal jobs. Tobacco farming has also led to more money to circulate in Nansanga, encouraging the emergence of small businesses in the area.

Through interviews and our observations, we know that tobacco is currently the leading cause of localized deforestation in Nansanga as more land is brought under tobacco growing, and as producers look for more woodfuel for curing tobacco. There are inconsistencies in the data on woodfuel consumption for tobacco curing by smallholders (Abdallah and Monela 2007). The average land under tobacco for both Mingomba and Kabundi is $0.7 \mathrm{ha}$, and average wood consumption per year is $44,000 \mathrm{~kg}\left(44 \mathrm{~m}^{3}\right)$ per household. The observed woodfuel requirement is $29 \mathrm{~kg}$ to cure $1 \mathrm{~kg}$ of tobacco. This figure is greater than four other study estimates of $11 \mathrm{~kg}, 12 \mathrm{~kg}, 14 \mathrm{~kg}$ and $19 \mathrm{~kg}$, estimated by Musoni et al. (2013) in Zimbabwe, Jew et al. (2017) in Tanzania, Munanga et al. (2017) in Zimbabwe and Mangora (2006) in Tanzania, respectively. However, it is comparable to the $31 \mathrm{~kg}$ reported by Jimu et al. (2017) in the miombo ecoregion. Despite the different figures, Jimu et al. (2017) observe that tobacco production threatens the miombo ecoregion, and accounts for $15 \%$ of deforestation in Zimbabwe and 26\% in Malawi.

Though Goma et al. (2017 p1) assert that "it is not at all clear if tobacco farming is even a livelihood worth pursuing for Zambians", our study suggests that under the current contractual conditions with TPL and the failure of the farm block, farmers will continue growing tobacco, and growers see it an ongoing livelihood option. There are only two conditions that can stop tobacco production in Nansanga: i) lack of woodfuel or other means of acquiring it; and ii) availability of alternative livelihoods that would be more lucrative than growing tobacco. Since the second is less plausible in the agricultural scenario in Nansanga, the lack of woodfuel is the only real issue. Tobacco production is providing employment, and farmers have additional income, enabling some of them to even buy cars, oxen and bicycles. Currently, our findings suggest a win-win situation between TPL and tobacco growers.

In the long term, however and as Rasmussen et al. (2018) note, tobacco production cannot be sustained. As in Geist (1999, p.18), tobacco production in Nansanga has emerged as "a particularly difficult dilemma for development as it generates a range of employment, income, foreign exchange, and other cash-contributing effects, while the damage to public health and to the environment in the long term appears substantially to outweigh the benefits."

\section{The political ecology of manganese open pit mining in Nansanga}

Nansanga was meant to attract investments in commercial agriculture and mining, based on its biophysical and demographic endowments. GRZ understood Nansanga as an area with potential for commercial agriculture (e.g 1,000-1,200mm annual rainfall), high unemployment and hence cheap labor, and the presence of rivers to support irrigation). Manganese mining began after the exploration and mining licenses were issued by the Ministry of Mines in Lusaka, the nation's capital. The institutionalized and power-laden policies in the government ministries, have led to the emergence of new actors with their own understanding and use of land (Robbins 2012). Though the mining companies obtained mining licenses from the Ministry of Mines to start mining in Nansanga (Inv-KII \#1, Nansanga, March 2018), interviews with key informants at the Ministries of Agriculture and Lands, and the Zambia Environmental Management Agency revealed a lack of knowledge about the mining operations within the farm block. This reveals silos within the institutional structures of GRZ, and policy inconsistencies (see Kalaba et al. 2014).

Manganese mining has become a lucrative economic activity for people within Nansanga and others leaving urban areas and seeking small enterprises. People are drawn to mining chiefly because payments are fast and predictable. Every month they are paid, while for tobacco and other crops, they must wait for seven to eight months. Manganese mining has also emerged as a non-agricultural alternative source of income in a rural, semi-subsistence economy where people grow their own food and undertake agricultural-related activities throughout the year.

Manganese mining is mainly being done on titled land that is part of the farm block program. With the titling of land in Nansanga, some community members suffering hardship are selling their prime asset, their land, to mining companies. Community members do not have access to information about the actual value of titled land, and therefore, sell land at 'give away' prices, particularly if they urgently need money. For example, 
1 ha of land could be sold for K5,000 ( US\$350) (K-KII \#, K-FGD \#4, Nansanga, March 2018). The failure to establish a farm block after enclaving customary land has fueled mistrust in GRZ and speculative sales of land by some community members. "We don't know what will happen next, it is better to sell the land, you get something rather than being evicted like our friends" (K-FGD \#3, Nansanga, March 2018). Chimhowu and Woodhouse (2006) also noted that, contrary to strengthening land rights and encouraging investments, land titling for economically poor communities can be a curse as it can lead to landlessness when they are in distress.

We found inherent contradictions between the visions of those supporting LSLA, and what actually happens as deals unfold. In the case of Nansanga, tobacco production and manganese open pit mining reveal two of the ways in which contradictions are revealed. Given Nansanga's development status, it can plausibly be suggested that a-win-win-win situation as initially envisioned through the farm block program is now unlikely. But tobacco production and manganese open pit mining do offer a partial window into the vision of the farm block, to the extent that a cash economy is slowly being established, and (some) members are gaining casual job opportunities, including emerging small business opportunities. This does not underplay or disregard the environmental and socio-economic concerns surrounding tobacco production and manganese mining. However, we must acknowledge some elements of the original Nansanga plan have been realized - livelihood opportunities.

It is important to recall that the state (through the Ministry of Agriculture and the Ministry of Lands) has assembled and defined Nansanga as a food crop production area. The same state (through the Ministry of Mines, and without the knowledge of the other ministries) redefined the use and users of Nansanga to promote mining by issuing mining licenses in an area that was initially assembled for food crop production. Tobacco farming (non-food, but unlicensed) could be perceived as 'tree mining' given the need for fuelwood; this new and unsustainable practice in Nansanga contrasts with the traditional chitemene shifting cultivation system where trees were pollarded, the branches were burn to fertilize fields, and land and trees recovered over time. Shifting cultivation is only practiced on customary land, highlighting that local production is embedded in political and policy processes that define Zambia's land tenure systems.

An understanding of the political and social processes as they are situated within Nansanga's biophysical realities needs to be nested within the prevailing bifurcated state and this customary land tenure system. The administration levels of state land and customary land determine the value and uses derived from it (including the management outcomes and impacts from land use). De jure, all land belongs to the national President. De facto, customary land is administered by traditional authorities and state land is administered by the Commissioner of Lands (Smith, 2004). However, the state can effect changes to management regimes and how customary land is treated, simply by claiming it is doing so in the public interest (GRZ 1995). The state can override the decisions of traditional authorities who are the de facto administrators. Using its legitimacy, the state in Zambia is therefore able to decide the utility of land, and when, by who, for how long and for whose benefit it may be used.

Using this legitimacy, the state (through the Ministry of Agriculture and the Ministry of Lands) converted customary tenure into leasehold for commercial agriculture, and again allowed manganese mining (through the Ministry of Mines). This is how the resourcefulness of customary land is constructed, alters over time, or morphs. Additionally, the material qualities of land shift along with land values (Li 2014) through state mediation. GRZ therefore, remains powerful in land tenure conversions for development purposes as they unfold.

Nansanga belongs to the Lala people in the Muchinda chiefdom, and this is legally recognized by the state. The state also recognizes that land under traditional authority is customary land. The legal recognition makes it possible for the Lala to define the (non-monetary) value of land - what they can use it for, when, how, and with boundaries that mark exclusion of access and use. It should be noted that this particular legal recognition of customary land renders it 'resourceless.' This is because customary land does not have market value and cannot be collateralized. Therefore, the way that the state has 'made' customary land as an environmental resource (Parenti 2015) is that it has no 'direct' monetary value in the capital accumulation equation for community members as the primary users. That is, customary land has no financial value, and therefore, no role in capital accumulation. For it to play a role in capital accumulation, it has to be re-defined, 
re-assembled and given a new meaning (Li 2014) through land tenure conversion. This re-definition gives land a new meaning and value for exploitation and capital accumulation. By extension, the re-definition of land also sets new political and social processes and boundaries regarding how old (community members) and new users (investors) will interact with land. Relating this to the Nansanga case, the old users, the Lalas, have lost political control of the Nansanga miombo woodland (their traditional rules of land governance) and social relations (community uses and values of the woodland). The new users, the investors who have bought land, have acquired the new value attributed to leased land, and new political and social control - raising the issue of how to govern and manage leased land as lessees, and how to make decisions regarding what to do with the land.

It should be noted that the political and social processes for both new and old users of Nansanga are influenced by the environmental resourcefulness or the affordances of land, including the physical dimensions of the area. In other words, land in Nansanga has the material presence and location with rich and diverse uses and values. These include the capacity to sustain human life ( $\mathrm{Li} 2014$ ) that influences political and social processes affecting new and old users. The re-definition of customary land through the conversion of land tenure has spatial dimensions, and thi has neem of particular concern to original land users and community members. The Senior Chief Muchinda lamented, '...how can I be a Senior Chief without land? Land is what defines my power and influence as a Senior Chief in this chiefdom.' If the Senior Chief with his legitimacy expressed his fears in those words, it is understandable that his less powerful subjects have deeper fears about land use and social change resulting from land access shifting to new users. These concerns range from scarcity of caterpillars, scarcity of certain socio-cultural tree species, deforestation and land degradation (from commercial tobacco production and open pit mining in particular). The disturbance of Nansanga's traditional land management regimes is of concern, for example bushfires occurring at wrong times of the year. Some Lala people consider the behaviors of newcomers to be licentious, and there is a sense that the simple presence of non-Lala is socially disruptive.

A change from customary to leasehold tenure has led to a transfer and conversion of largely 'nonmonetary use values' (enjoyed relatively equitably across the community) to 'monetary use values' for a far smaller group of people (land-owners), often from outside the community for capital accumulation. Nansanga cannot be discounted as marginal land (see Chilombo, 2021). In fact, the political and social processes of both community members and investors are linked to the 'environmental resourcefulness' of the area. The redefinition of land tenure in Nansanga has been political, social, and environmental. This re-definition has led to the transfer of the environmental resources and their 'resourcefulness' from community members to investors.

It should be noted here that a cashless economy operated in Nansanga, and could have remained so were it not for the establishment of the farm block. Manganese mining then replaced cash cropping when the farm block was less successful than originally planned.

\section{Conclusion}

The implementation of LSLA deals is punctuated with cancellations, scaling back, land abandonment or changes to investment business models. In this article, we aimed at understanding the political ecology of tobacco production and manganese mining that have emerged and flourished as opportunistic economic activities in the Nansanga farm block, an area that was previously under customary tenure. We have attempted to account for the socio-environmental changes perceived by the local people in Nansanga as development has failed to advance, and how these changes are distributed among stakeholders.

Our findings suggest that corruption and self-serving political party interests in the public-funded rural agricultural development program contributed to the uneven development of Nansanga. After the original investors withdrew and without active control by the state, wealthier outside business entities have arrived with extractive and poorly regulated economic activities. After initial government investment languished, tobacco production and manganese mining filled the development vacuum. Their socioeconomic success has been patchy, with localized environmental degradation. It was the absence of GRZ that enabled their entrance: 'when the cat is away, the mice will play.' Local communities are disproportionately bearing the brunt of environmental degradation, while outsiders (including companies and non-Lala job-seekers) are the beneficiaries of mining and commercial tobacco. Land for the local Lalas in Nansanga is not only a means of 
production, but it is also their territory. It marks their identity as a people - there would be no Lalaland without Lalas, or Lalas without Lalaland.

Finally, as these activities accelerate the privatization and degradation of land, the short-term gains of more paid employment cannot mask the weakening of group identity and cultural cohesion, labor flight from food crop production, growing wealth inequality, diminished self-sufficiency due to landlessness, and the eventual de-lalalization of Nansanga.

\section{References}

Abbot, J. I. (1996). Rural subsistence and protected areas: Community use of the miombo woodlands of Lake Malawi National Park. PhD Thesis, University College London.

Abdallah, J. M., \& Monela, G. G. (2007). Overview of Miombo woodlands in Tanzania. Finnish Forest Research Institute, 50, 9-23.

Adams, M. (2003). Land tenure policy and practice in Zambia: issues relating to the development of the agricultural sector. Draft.

Ahmed, A., Campion, B. B., \& Gasparatos, A. (2017). Biofuel development in Ghana: Policies of expansion and drivers of failure in the jatropha sector. Renewable and Sustainable Energy Reviews, 70, $133-149$. https://doi.org/10.1016/j.rser.2016.11.216

Antwi-Bediako, R. (2018). Chiefs and nexus of challenges in land deals: An insight into blame perspectives, exonerating chiefs during and after Jatropha investment in Ghana. Cogent Social Sciences, 4(1), 1-20. https://doi.org/10.1080/23311886.2018.1456795

Ariza-Montobbio, P., Lele, S., Kallis, G., \& Martinez-Alier, J. (2010). The political ecology of Jatropha plantations for biodiesel in Tamil Nadu, India. Journal of Peasant Studies, 37(4), 875-897.

Baglioni, E., \& Gibbon, P. (2013). Land grabbing, large- and small-scale farming: What can evidence and policy from 20th century Africa contribute to the debate? Third World Quarterly, 34(9), 1558-1581.

Boche, M., \& Answeeuw, W. (2013). Unraveling "Land grabbing:" Different models of large scale land acquisitions in Southern Africa. LDPI Working Paper 46. https://agritrop.cirad.fr/570481/

Borras, S. M., \& Franco, J. C. (2012). Global land grabbing and trajectories of agrarian change: A preliminary analysis. Journal of Agrarian Change, 12(1), 34-59. https://doi.org/10.1111/j.1471-0366.2011.00339.x

Borras, S. M., Franco, J. C., Gómez, S., Kay, C., \& Spoor, M. (2012). Land grabbing in Latin America and the Caribbean. Journal of Peasant $845-872$. https://doi.org/10.1080/03066150.2012.679931

Brouwer, R., \& Falcão, M. P. (2004). Wood fuel consumption in Maputo, Mozambique. Biomass and Bioenergy, 27(3), 233-245. https://doi.org/10.1016/j.biombioe.2004.01.005

Calder, B. J. (1977). Focus groups and the nature of qualitative marketing research. Journal of Marketing Research, 14(3), 353. https://doi.org/10.2307/3150774

Campbell, J. R. (2001). Participatory Rural Appraisal as qualitative research: From participatory claims. Human Organization, 60(4), 380-389.

Chandra, G. (2010). Participatory Rural Appraisal. In Katiha, P. K., Vaas, K.K., Sharma, A. P., Bhaumik, U. \& C. Ganesh (eds.), Issues and tools for social science research in inland fisheries. Bulletin \# 163, 286302. Central Inland Fisheries Research Institute, Kolkata, India.

Cherry, L. (2002). ' New Deal ' in Zambia points the way. Executive Intelligence Review, 29(11), 12-13.

Chidumayo, E. N. (1987). Species structure in Zambian miombo woodland. Journal of Tropical Ecology, 3(2), 109-118. https://doi.org/http://dx.doi.org/10.1017/S0266467400001838

Chilombo, A. (2019). Understanding socio-economic and environmental impacts of large-scale land acquisitions: A case study of Nansanga Farm Block in Zambia. PhD Thesis, University of Edinburgh, UK. Retrieved from https://era.ed.ac.uk/handle/1842/36391 
Chilombo, A. (2021). Questioning the narrative of land marginality in large-scale land acquisition deals : case study of Nansanga Farm Block in Zambia. Journal of Land Use Science, 16(2), 188204, http://doi.org/10.1080/1747423X.2021.1882599

Chilombo, A., Fisher, J. A., \& van der Horst, D. (2019). A conceptual framework for improving the understanding of large scale land acquisitions. Land Use Policy, 88, 104184. https://doi.org/10.1016/j.landusepol.2019.104184

Chimhowu, A., \& Woodhouse, P. (2006). Customary vs private property rights? Dynamics and trajectories of vernacular land markets in sub-Saharan Africa. Journal of Agrarian Change, 6(3), 346-371. https://doi.org/10.1111/j.1471-0366.2006.00125.x

Cotula, L., Vermeulen, S., Leonard, R., \& Keeley, J. (2009). Land grab or development opportunity? Agricultural Investment and International Land Deals in Africa? IIED.

De Schutter, O. (2011). How not to think of land-grabbing: three critiques of large-scale investments in farmland. Journal of Peasant Studies, 38(2), 249-279. https://doi.org/10.1080/03066150.2011.559008

Deininger, K., \& Byerlee, D. (2012). The rise of large farms in land abundant countries: Do they have a future? World Development, 40(4), 701-714. https://doi.org/10.1016/j.worlddev.2011.04.030

Deligiannis, T. (2012). The evolution of environment-conflict research: Toward a livelihood framework. Global Environmental Politics, 12(1), 78-100. https://doi.org/10.1162/GLEP_a_00098

DiCicco-Bloom, B., \& Crabtree, B. F. (2006). The qualitative research interview. Medical Education, 40(4), 314-321. https://doi.org/10.1111/j.1365-2929.2006.02418.x

FAO \& UNHCR. (2017). Rapid woodfuel assessment, 2017 baseline for the Bidibidi settlement, Uganda Woodfuel. FAO.

Faugier, J., \& Sargeant, M. (1997). Sampling hard to reach populations. Journal of Advanced Nursing, 26(4), 790-797. https://doi.org/10.1046/j.1365-2648.1997.00371.x

Fingermann, N. N. (2015). A study of Brazilian Trilateral Development Cooperation in Mozambique: The case of ProSAVANA and ProALIMENTOS. CBAA Working Papers 19. Retrieved from http://www.future-agricultures.org/research/cbaa/8031-china-brazil-paper-series

Fox, J. (1984). Firewood consumption in a Nepali village. Environmental Management, 8(3), 243-249. https://doi.org/10.1007/BF01866966

Frost, P. (1996). The ecology of miombo woodlands. In Campbell, B. (ed.), The miombo in transition: woodlands and welfare in Africa. CIFOR.

Geist, H. J. (1999). Global assessment of deforestation related to tobacco farming. Tobacco Control, 8(1), 1828. https://doi.org/10.1136/tc.8.1.18

Goma, F., Drope, J., Zulu, R., Li, Q., Chelwa, G., Labonte, R., \& Banda, J. (2017). The economics of tobacco farming in Zambia. University of Zambia School of Medicine and Atlanta: American Cancer Society.

GRZ. (1995). The Lands Act. Government of Zambia.

GRZ. (2005). Farm Block Development Plan (2005-2007). Government of Zambia.

Hakizimana, C., Goldsmith, P., Nunow, A. A., Roba, A. W., \& Biashara, J. K. (2017). Land and agricultural commercialisation in Meru County, Kenya: Evidence from three models. Journal of Peasant Studies, 44(3), 555-573. https://doi.org/10.1080/03066150.2016.1260555

Hall, R. (2010). The many faces of the investor rush in Southern Africa : Towards a typology of commercial land deals. Transnational Institute.

Higginbottom, G. M. A. (2004). Sampling issues in qualitative research. Nurse Researcher, 12(1), 7-19. https://doi.org/10.7748/nr2004.07.12.1.7.c5927

Jayne, T. S., Chamberlin, J., \& Headey, D. D. (2014). Land pressures, the evolution of farming systems, and development strategies in Africa: A synthesis. Food Policy, 48, 1-17. https://doi.org/10.1016/j.foodpol.2014.05.014 
Jew, E. K. K., Dougill, A. J., \& Sallu, S. M. (2017). Tobacco cultivation as a driver of land use change and degradation in the miombo woodlands of south-west Tanzania. Land Degradation and Development, 28(8), 2636-2645. https://doi.org/10.1002/ldr.2827

Jimu, L., Mataruse, L., Musemwa, L., \& Nyakudya, I. W. (2017). The miombo ecoregion up in smoke: The effect of tobacco curing. World Development Perspectives, 5, 44-46. https://doi.org/10.1016/j.wdp.2017.03.007

Jumbe, C. B. L., Bwalya, S. M., \& Husselman, M. (2009). Contribution of dry forests to rural livelihoods and the national economy in Zambia. XIII World Forestry Congress, (October), 18-23.

Kalaba, F. K., Quinn, C. H., \& Dougill, A. J. (2013). Contribution of forest provisioning ecosystem services to rural livelihoods in the Miombo woodlands of Zambia. Population and Environment, 35(2), $159-182$. https://doi.org/10.1007/s11111-013-0189-5

Kalaba, F. K., Quinn, C. H., \& Dougill, A. J. (2014). Policy coherence and interplay between Zambia's forest, energy, agricultural and climate change policies and multilateral environmental agreements. International Environmental Agreements: Politics, Law and Economics, 14(2), 181-198. https://doi.org/10.1007/s10784-013-9236-z

Katz-Lavigne, S. (2016). Property rights and large-scale mining: overlapping claims at and around mining sites at the Democratic Republic of Congo and Zambia. Third World Thematics: a TWQ Journal, 1(2), 202217. https://doi.org/10.1080/23802014.2016.1196604

Kendall, C., Kerr, L. R. F. S., Gondim, R. C., Werneck, G. L., Macena, R. H. M., Pontes, M. K., ... McFarland, W. (2008). An empirical comparison of respondent-driven sampling, time location sampling, and snowball sampling for behavioral surveillance in men who have sex with men, Fortaleza, Brazil. AIDS and Behavior, 12(SUPPL. 1), 97-104. https://doi.org/10.1007/s10461-008-9390-4

Kitzinger, J. (1995). Qualitative Research: Introducing focus groups. British Medical Journal, 311(7000), 299. https://www.ncbi.nlm.nih.gov/pmc/articles/PMC2550365/

Li, T. M. (2011). Centering labor in the land grab debate. Journal of Peasant Studies, 38(2), $281-298$. https://doi.org/10.1080/03066150.2011.559009

Li, T. M. (2014). What is land? Assembling a resource for global investment. Transactions of the Institute of British Geographers, 39(4), 589-602. https://doi.org/10.1111/tran.12065

Makki, F., \& Geisler, C. (2011). Development by dispossession: Land grabbing as new enclosures in contemporary Ethiopia. Global Land Grabbing conference. Retreived from: https://www.futureagricultures.org/wp-content/uploads/pdf-archive/Fouad\%20Makki\%20and\%20Charles\%20Geisler.pdf

Mangora, M. M. (2006). Ecological impact of tobacco farming in miombo woodlands of Urambo District, Tanzania. African Journal of Ecology, 43(4), 385-391. https://doi.org/10.1111/j.13652028.2005.00603.x

McMichael, P. (2012). The land grab and corporate food regime restructuring. Journal of Peasant Studies, 39(3-4), 681-701. https://doi.org/10.1080/03066150.2012.661369

Moreda, T. (2017). Large-scale land acquisitions, state authority and indigenous local communities: insights from Ethiopia. Third World Quarterly, 38(3), 698-716. https://doi.org/10.1080/01436597.2016.1191941

Morgan, D. L. (2008). Focus groups. The Sage encyclopedia of qualitative research. (pp. 353-355). Sage.

Munanga, W., Mugabe, F. T., Kufazvinei, C., \& Dimbi, S. (2017). Development of a low cost and energy efficient tobacco curing barn in Zimbabwe. African Journal of Agricultural Research, 12(35), 27042712. https://doi.org/10.5897/AJAR2017.12413

Murphy, E., Dingwall, R., Greatbatch, D., Parker, S., \& Watson, P. (1998). Qualitative research methods in Health Technology Assessment: A literature review. Health Technology Assessment, 2(16), 1-276. https://doi.org/10.3310/hta2160 
Musoni, S., Nazare, R., Manzungu, E., \& Chekenya, B. (2013). Redesign of commonly used tobacco curing barns in Zimbabwe for increased energy efficiency. International Journal of Engineering Science and Technology, 5(03), 609-617.

Offen, K. H. (2004). Historical political ecology: An introduction. Historical Geography, 32, 19-42.

Parenti, C. (2015). The 2013 ANTIPODE AAG Lecture The environment making state: territory, nature, and value. Antipode, 47(4), 829-848. https://doi.org/10.1111/anti.12134

Rasmussen, L. V., Coolsaet, B., Martin, A., Mertz, O., Pascual, U., Corbera, E., ... Ryan, C. M. (2018). Socialecological outcomes of agricultural intensification. Nature Sustainability, 1(7), 275-282. https://doi.org/10.1038/s41893-018-0070-8

Robbins, P. (2012). Political ecology: A critical introduction. London: Wiley.

Roudart, L., \& Mazoyer, M. (2015). Large-Scale Land Acquisitions: A historical perspective. International Development Policy | Revue Internationale de Politique de Développement [Online], 6, 1-29. https://doi.org/10.4000/poldev.2088

Ryan, C. M., Pritchard, R., McNicol, I., Owen, M., Fisher, J. A., \& Lehmann, C. (2016). Ecosystem services from southern African woodlands and their future under global change. Philosophical Transactions of the Royal Society B: Biological Sciences, 371(1703), 20150312. https://doi.org/10.1098/rstb.2015.0312

Schoneveld, G. C. (2017). Host country governance and the African land rush: 7 reasons why large-scale farmland investments fail to contribute to sustainable development. Geoforum, 83, 119-132. https://doi.org/10.1016/j.geoforum.2016.12.007

Sitko, N. J., \& Chamberlin, J. (2016). The geography of Zambia's customary land: Assessing the prospects for smallholder development. Land Use Policy, 55, 49-60. https://doi.org/10.1016/j.landusepol.2016.03.026

Smith, R. E. (2004). Land tenure, fixed investment, and farm productivity: Evidence from Zambia's southern province. World Development, 32(10), 1641-1661. https://doi.org/10.1016/j.worlddev.2004.05.006

Walker, P. (2006). Political ecology: where is the policy? Progress in Human Geography, 30(3), 382-395.

Wolford, W., Borras, S. M., Hall, R., Scoones, I., \& White, B. (2013). Governing global land deals: The role of the state in the rush for land. Development and Change, 44(2), 189-210. https://doi.org/10.1111/dech.12017

World Bank. 2009. Awakening Africa's sleeping giant : prospects for commercial agriculture in the guinea savannah zone and beyond. World Bank. http://hdl.handle.net/10986/2640 